\title{
Eldercare policies in Scandinavia between 1993 and 2014: Increased facilitation of family caregiving?
}

\author{
Christine Thokle Martens \\ Norwegian Social Research (NOVA) \\ Oslo Metropolitan University, Norway \\ Email: christinemartens@yahoo.com
}

\begin{abstract}
This article asks whether legal rights provided through national legislation on services provision in Scandinavia have become, over time, more accommodating to the role of family caregiving to elderly relatives. The study is based on a comparison and analysis of changes in legislation between 1993 and 2014 in the three Scandinavian countries. It is limited to legislation on the right to eldercare services and on work-family facilitating policies in relation to the provision of care to an elderly relative. Work-family facilitating policies are those policies that enable the combining of employment in the formal economy with caring for family members without large prohibitive costs for the caregiver. The main findings in this article are that the Scandinavian countries strengthened the legal right to public care services between 1993 and 2014, but that there are few, if any, truly work-family facilitating policies. The existing schemes do not facilitate a combination of employment and care, but rather force the family caregiver to choose between them. The dilemma is whether to continue passively with a high, but declining, level of public service provision of eldercare, leaving unmet care needs to unpaid family carers, or to introduce work-family facilitating policies enabling remunerated family care in addition to extensive public services provision.
\end{abstract}

Keywords: Work-family facilitation, eldercare, ageing population, Nordic model, welfare mix, informal care

\section{Introduction}

Population ageing is one of the main drivers of societal change in Scandinavia and other European countries, requiring policy reforms that support an increase in labour force participation combined with reforms ensuring a balance between work and family care. Sweden, Norway and Denmark can be described as dualearner, or adult worker, countries (Korpi, 2000; Lewis \& Giullari, 2005). High female employment rates have been achieved by providing extensive public care services for the elderly and for children. These countries are also distinguished by a very high reliance on public spending on long-term care. It 
is, however, unclear to what extent the Scandinavian model of extensive, public, long-term care will be sustainable over the next few decades without a greater role for family care provision.

This article originates in the literature on familialism. To de-familialise care means, according to a large section of the scholarly literature, that the responsibility for care is removed from the family and with it the dependence on family members for care (Esping-Andersen, 1999; Leitner, 2003). In the literature, the Nordic welfare states are often considered de-familialised because of a more generous provision of public eldercare services than other welfare states. De-familialisation is also understood as economic independence from family relationships (Lister, 1994). A decline in publicly provided care services would lead to a larger need for family care, which is incompatible with extensive labour force participation. So far, there is no agreement in the literature on the extent of work-family facilitation policies in these states (Leitner, 2003, p. 363; Saraceno, 2010, p. 38).

The purpose of this article is to provide an empirical foundation for the future discussion of the degree and type of de-familialism in the Nordic welfare states. Whether and how national governments have put in place work-family facilitating policies to compensate for a possible decline in publicly provided eldercare, is an important question. Thus, the research question is whether legal rights provided through national legislation on services provision in Scandinavia have become, over time, more accommodating to the role of family caregiving to elderly relatives.

This article's empirical investigation does not relate to familialism but is limited to the concept of work-family facilitating policies. The article conducts a comparison and analysis of changes in legislation between 1993 and 2014 in the three Scandinavian countries, limited to legislation on the right to eldercare services and on work-family facilitating policies in relation to the provision of care to an elderly relative.

Extensive public care services provision allows adults to enter into and stay in the workforce (Esping-Andersen, 1990, p. 28). Although the welfare state relieves the family of care obligations, work and family are not two separate domains (Revillard, 2006, p. 134; Voydanoff, 2004, p. 398). The two spheres affect one another and can lead to work-family conflict and a double burden of employment and caring for children and elderly parents (Daatland, Veenstra, \& Lima, 2010; Gautun, 2008; Jakobsson, Kotsadam, \& Szebehely, 2013; Knijn \& Kremer, 1997; Sand, 2010). Greenhaus and Beutell (1985) define work-family conflict as 'a conflict in which the role pressures from the work and family domains are mutually incompatible in some respect' (p. 77). Consequently, work-family facilitation can be defined as 'a form of synergy in which resources associated with one role enhance or make easier participation in the other role' (Voydanoff, 2004, p. 399). Policies on public services provision constitute such work-family facilitating resources; they facilitate combining employment in the formal economy with caring for family members without large prohibitive costs for the caregiver. Provision of public care services allows for participation in the workforce, and rights to flexible working hours, employment protection and benefits allow for family caregiving. 
Figure 1. Coverage levels of eldercare services. Number of persons aged 65 and over living in residential care or receiving home help, as a percentage of the population 80 and over (Source: NOSOSCO, 1995-2015)

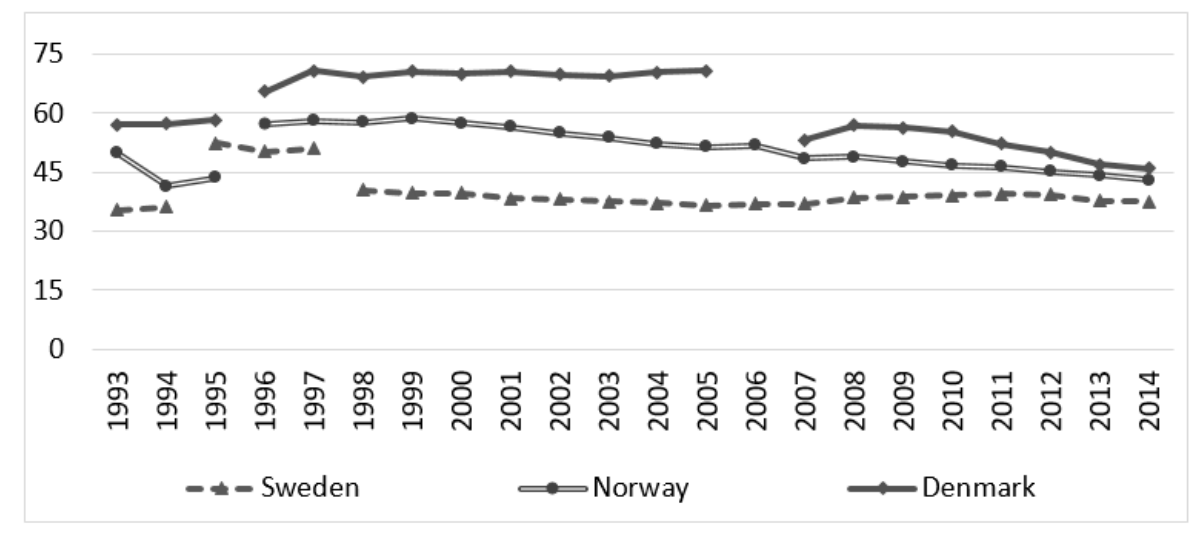

Sweden: percentage of the population 75+ in 1993-1994. From 1998, short-term stays in institutions and home help in service housing are excluded. For 2007, 2009 and 2010, the percentages are estimated based on the coverage levels the preceding and succeeding years.

Norway: percentage of the population 75+ in 1993-1995. For 2009 and 2013, the percentages are estimated based on the coverage levels the preceding and succeeding years.

Denmark: percentage of the population 75+ in 1993-1995. From 2008, home help in service housing is excluded and there is a change in the statistics, probably excluding short-term stays.

Several studies to date have shown an overall decline in services provision in the Scandinavian countries since the 1980s and 1990s (Nielsen \& Andersen, 2006, pp. 59-60; Otnes, 2015, pp. 53-54; Trydegård \& Thorslund, 2010). Comparative statistics on public eldercare services coverage in these countries show a tendency of converging coverage levels of eldercare between the three countries (NOSOSCO, 1995-2015). Denmark has had the highest coverage level since 1993, while Sweden has had the lowest (see Figure 1). Since 2008, both Norway and Denmark have shown a decline in coverage levels, converging towards the level of Sweden. In all three countries, albeit to varying degrees, fewer recipients receive more care, and there has been an increased focus on medical assistance and bodily needs at the expense of practical help (Daatland, 2014; Lewinter, 2004; Szebehely \& Trydegård, 2007, p. 211; Vabø \& Szebehely, 2012, p. 132). Needs assessments have become stricter and the definition of 'need' has been limited to medical assistance and physical needs. These developments have placed more responsibility for care provision on the family and the individual (Vabø \& Szebehely, 2012, p. 134) and, thus, created significant tensions between care needs in the population and the ability of adult family members to provide eldercare.

\section{Conceptual framework}

Public eldercare services provision, including cash-for-care schemes, is defined as the provision of benefits and services financed by public bodies and regulated by national legislation. In Scandinavia, public eldercare services provision is a municipal responsibility, but it is regulated by national 
governments through national legislation (Andreotti, Mingione, \& Polizzi, 2012, p. 1936). Municipal care services are funded mainly through block grants from central government (i.e., grants not earmarked for care services in particular), in addition to local taxes, which are defined within a specific range that is set by central government (Jensen \& Lolle, 2013; KMD, 2015; Trydegård \& Thorslund, 2010). This formal division of responsibility implies a delegation of authority to the local governments. Thus, the municipalities are simultaneously organisational tools for achieving national policy goals and autonomous units responsible for providing services to their citizens (Grønlie, 2004).

The legislation is here interpreted as an operationalisation of national policies. Legislation can provide rights to the individual, or it can impose duties on public bodies like municipalities (Dean, 2014). How these different ways of formulating legislation affect individual service recipients is illustrated by the conceptual model in Figure 2. Granting rights to individuals directly (Linkages 1 and 2) leads to a standardization of services and restricts local discretion, as everyone in a particular situation will have a legal right to the same services (Fimreite, 2003, p. 343). This requires objective inclusion criteria and unlimited resources to fulfil the rights. By imposing requirements on municipalities rather than granting legal rights (Linkage 3), legislation indirectly affects the fulfilment of care needs and possibilities for work-family facilitation through municipal services provision (Linkages 4 and 5).

Figure 2. Conceptual model

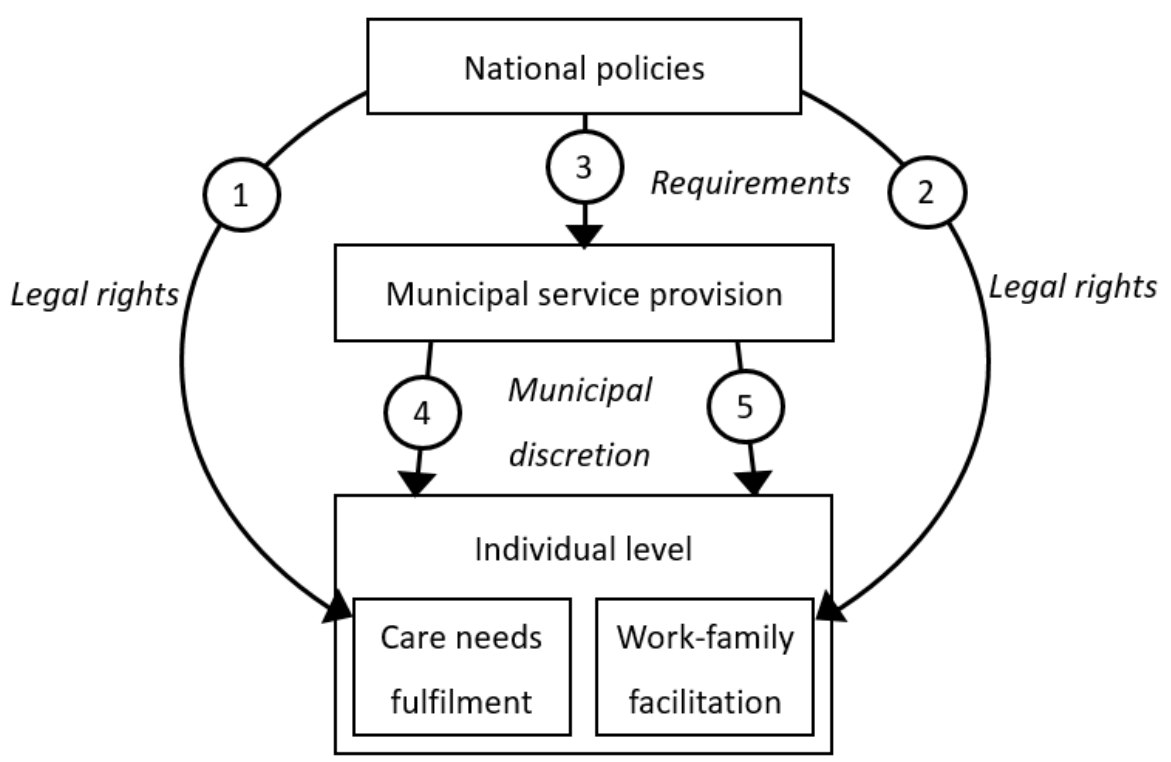

When the responsibility for services provision is divided between policy levels, the main principle is that the national level handles economic transfers and rights that are universalistic in character, such as specialist health care and the social security system. Services provision and transfers that are prone to individual discretion and local conditions are handled at the local level (Powell 
\& Boyne, 2001, p. 184). This structure normally means that national policies pose specific demands and performance criteria on local policies and services provision through, among others, legislation. To meet national performance criteria, the local level must develop strategies that correspond with local needs (van Gestel \& Herbillon, 2010, p. 417).

The organization of services provision can affect the strength of rights or, in other words, whether rights are strong or weak (Hatland, 2007). A strong right is typically clear and unconditional, while weak rights are claims that have to be assessed on a discretionary basis. A weak legal right within municipal services provision is typically a right that is subject to municipal discretion. Leira and Saraceno (2002) label such rights 'supply-conditioned rights', meaning that the right is an expression of the government's intent but is not necessarily an entitlement in the here and now (p. 75). This is the case when national legislation imposes requirements on municipal services provision, and municipal gatekeepers restrict the availability of services through discretionary assessments. Weak legal rights prone to municipal discretion are often an area of contention. The demarcation criteria for having a claim to a benefit or service are not clear, which can lead to discrepancies between inhabitants' perceived rights to a specific service and municipal assessments. This is typically the case when municipal assessments also depend on scarce municipal resources.

\section{Analytical approach}

This article contains a comparison of legislation in Sweden, Norway and Denmark. The study is limited to the period of 1993-2014 because of the data availability of statistics from NOSOSCO. The comparison is based on most similar systems designs. In such a design, it is assumed that the countries have many features in common, and these features can be ignored because they are believed to be equal (Sartori, 2009, p. 156). These countries do share similarities, such as municipal autonomy and responsibility for service provision within the limits of national legislation and public provision of extensive social care services (Edebalk \& Svensson, 2005, p. 35; Kröger, 2001, p. 16). It is a widespread belief that the differences between the Scandinavian countries' service models 'are outweighed by the similarities when compared to other countries in the world' (Sipilä et al., 1997, p. 39). The reason for including three welfare states in the analysis is to ascertain whether there is also a Nordic model in the area of legislation on eldercare services provision and work-family facilitation policies. The remaining Nordic countries (Iceland and Finland) were excluded because of the language barrier.

The comparison rests on a thorough document analysis. The main databases for national policies and legislation in the three countries are Lovdata.no, Retsinformation.dk and Svensk författningssamling. The current study used these databases to conduct a systematic review of each country's legislation. First, the databases were searched for legal documents containing the words 'care', 'leave of absence', 'relative' and 'work environment'. Secondary data sources, such as government documents and academic articles, were consulted to aid the data search. Second, when an act in one of the countries was found to contain a regulation on combining work and care or receiving care, a search for a corresponding right in the other countries was conducted. All identified relevant sections of each country's legislation were downloaded into a database. Upon ending the systematic review, the database of relevant sections of each act was systematized in a spreadsheet according to country, year and kind of right, and then translated into English. 


\section{Legal rights to public care services in 1993}

Table 1 presents legislation in Sweden, Norway and Denmark in 1993 on the right to care services and municipal responsibility for service provision. Only in Sweden did people have a legal right to social assistance, but only if their needs could not be met in any other way (Linkage 1 in Figure 2). There was a legal right to health care services in Norway, but not to social assistance. However, Norwegians had a legal right to cash-for-care, which allowed recipients to pay for privately-arranged care services. Danish legislation provided no legal rights to care services.

Table 1. National legislation on the right to public eldercare services in 1993. Country, right, (Legal Source)

\begin{tabular}{|c|c|c|}
\hline Sweden & Norway & Denmark \\
\hline CARE SERVICES & CARE SERVICES & CARE SERVICES \\
\hline $\begin{array}{l}\text { - The individual is entitled to assistance } \\
\text { from the social services if their needs } \\
\text { cannot be met in any other way (Social } \\
\text { Services Act, } 1980 \S 6 \text { ) }\end{array}$ & $\begin{array}{l}\text { - Everyone has a right to necessary } \\
\text { health care in the municipality where } \\
\text { he/she lives (Municipal Health Care Act, } \\
1982 \S 2-1 \text { ) }\end{array}$ & $\begin{array}{l}\text { - The public is obliged to aid everyone } \\
\text { who stays in the country (Social } \\
\text { Assistance Act, } 1992 \S 1 \text { ) }\end{array}$ \\
\hline $\begin{array}{l}\text { - The social services should provide } \\
\text { home help, service and care, and day } \\
\text { care. They shall provide home help and } \\
\text { other easily accessible services to } \\
\text { those in need. For elderly people with } \\
\text { special needs, the municipality must } \\
\text { establish homes with services (Social } \\
\text { Services Act, } 1980 \S \S 10,20 \text { ) }\end{array}$ & $\begin{array}{l}\text { - The municipality shall offer necessary } \\
\text { health care services, including care, to } \\
\text { its entire population by providing, } \\
\text { among other things, home nursing and } \\
\text { nursing homes (Change of the } \\
\text { Municipal Health Care Act, } 1986 \text {; } \\
\text { Municipal Health Care Act, } 1982 \S \S 1-1 \text {, } \\
1-3 \text { ) }\end{array}$ & $\begin{array}{l}\text { - The municipality shall ascertain that } \\
\text { there is a home care service that } \\
\text { provides practical home assistance by } \\
\text { home-helpers trained to carry out these } \\
\text { duties. Home care is provided for } \\
\text { practical assistance and personal care } \\
\text { to those who cannot provide this for } \\
\text { themselves (Social Assistance Act, } \\
1992 \S \S 50,53)\end{array}$ \\
\hline $\begin{array}{l}\text { - The county shall offer good health } \\
\text { care access to those residing in the } \\
\text { county. The municipality may offer } \\
\text { home care services to its citizens } \\
\text { (Health Care Act, } 1982 \S \S 3,18 \text {; Prop } \\
\text { 1990/91:14) }\end{array}$ & $\begin{array}{l}\text { - To those who cannot care for } \\
\text { themselves, services can be provided in } \\
\text { nursing homes or other institutions and } \\
\text { as home care (Social Care Act, } 1964 \\
\text { §) }\end{array}$ & $\begin{array}{l}\text { - The municipality shall provide } \\
\text { residential care to those who need it } \\
\text { due to their health (Social Assistance } \\
\text { Act, } 1992 \text { §79) }\end{array}$ \\
\hline CASH-FOR-CARE & CASH-FOR-CARE & CASH-FOR-CARE \\
\hline $\begin{array}{l}\text { - Depending on extent of need, paid to } \\
\text { care recipient (Municipal decisions) }\end{array}$ & $\begin{array}{l}\text { - Allowance to pay for private care, } € 85 \\
\text { /month (1995) (Change of the Social } \\
\text { Insurance Act, 1991; Social Insurance } \\
\text { Act, } 1966 \text { §8-2) }\end{array}$ & - None \\
\hline
\end{tabular}

In 1993, all three countries provided a right to social services through municipal services provision (Linkage 3 in Figure 2). Swedish legislation stated that municipalities should provide home care services and aim for good housing for the elderly. The municipalities also had to establish residential care facilities. In Norway, municipalities were obliged to offer necessary care services, including home care services and nursing homes. In Denmark, the municipalities had to ensure that home care services and residential care were provided to those who could not provide these for themselves.

In addition, some Swedish municipalities provided a cash-for-care benefit to care recipients (Linkage 4 in Figure 2). 


\section{Legal rights to public care services in 2014}

Table 2 presents legislation on the right to care services and municipal responsibility for services provision in 2014. Since then, Swedish citizens have had a legal right to services from the municipality if their needs cannot be met in any other way (Linkage 1 in Figure 2). Norwegian citizens have a right to necessary care services, but do not have an entitlement to a specific service (Prop. 91 L, 2010-2011). Furthermore, in Norway, all persons who are in need of attendance and care because of durable illness or injury and who receive privately arranged care have a right to a cash-for-care benefit. Danish citizens have a legal right to the services described in the Social Services Act.

Table 2. National legislation on the right to public eldercare services in 2014. Country, right, (Legal Source)

\begin{tabular}{|c|c|c|}
\hline Sweden & Norway & Denmark \\
\hline CARE SERVICES & CARE SERVICES & CARE SERVICES \\
\hline $\begin{array}{l}\text { - Those who cannot meet their needs } \\
\text { themselves, or whose needs cannot be } \\
\text { met in any other way, are entitled to } \\
\text { assistance from social services (Social }\end{array}$ & $\begin{array}{l}\text { - Patients and users have a right to } \\
\text { necessary municipal health and care } \\
\text { services (Patients' Rights Act, } 1999 \text { §2- } \\
\text { 1a) }\end{array}$ & $\begin{array}{l}\text { - Everyone legally residing in the } \\
\text { country is entitled to services stated in } \\
\text { this act (Social Services Act, } 2014 \S 2 \text { ) }\end{array}$ \\
\hline $\begin{array}{l}\text { Services Act, } 2001 \text { ch } 4, \S 1 \text { ) } \\
\text { - The social services shall endeavour to } \\
\text { provide older people with good housing } \\
\text { and shall provide home help and other } \\
\text { easily accessible services to those in }\end{array}$ & $\begin{array}{l}\text { - The municipality shall ensure that its } \\
\text { entire population is offered necessary } \\
\text { health and care services, including } \\
\text { home care services and nursing homes } \\
\text { (Municipal Health and Care Services }\end{array}$ & $\begin{array}{l}\text { - Municipalities shall offer home care } \\
\text { services for personal care, practical } \\
\text { help and food delivery services to those } \\
\text { who cannot provide this for themselves } \\
\text { (Social Services Act, } 2014 \S 83 \text { ) }\end{array}$ \\
\hline $\begin{array}{l}\text { need. The municipality must establish } \\
\text { sheltered homes with services and care } \\
\text { for elderly people with special needs. } \\
\text { (Change of the Social Services Act, } \\
2010 \text { ch } 5 \text { §5) }\end{array}$ & Act, 2011 §§3-1, 3-2) & $\begin{array}{l}\text { - Municipalities shall offer long-term } \\
\text { accommodation in appropriate housing } \\
\text { to persons in need of extensive care } \\
\text { due to physical or mental impairments } \\
\text { whose needs cannot be met in any } \\
\text { other way (Social Services Act, } 2014 \\
\S 108)\end{array}$ \\
\hline CASH-FOR-CARE & CASH-FOR-CARE & CASH-FOR-CARE \\
\hline $\begin{array}{l}\text { - Depending on extent of need, paid to } \\
\text { care recipient (Municipal decisions) }\end{array}$ & $\begin{array}{l}\text { - Allowance to pay for private care, } € \\
125 \text { /month (2014) (Social Insurance } \\
\text { Act, } 1997 \S 6-4)\end{array}$ & - None \\
\hline
\end{tabular}

As of 2014, the municipalities are held responsible for services provision in all three countries (Linkage 3 in Figure 2). Swedish legislation states that the social services shall provide home help and other easily accessible services to those in need and that they shall establish residential care. In Norway, the municipality is obliged to offer necessary health and care services to its entire population. These services should include home care services and nursing homes. The Danish Social Services Act states that the municipality shall offer care and support for personal needs, help and support for domestic practical chores and food delivery services to persons who cannot provide this for themselves due 
to physical or mental impairment. Danish municipalities are also obliged to provide residential care.

Lastly, some Swedish municipalities provide a cash-for-care benefit to care recipients (Linkage 4 in Figure 2).

\section{Changes in the legal right to public care services between 1993 and 2014}

In 1993, only Sweden provided a legal right to care services, but by 2014 , a legal right to social care services existed in all three countries. In this regard, legislation in the three countries has converged towards more legal rights for the individual. However, these rights are weak in the sense that they do not state specific rights to specific services. The rights depend on municipal services provision and municipal discretion. Hence, they are supply-conditioned rights, meaning that they cannot be fulfilled unless there is an actual municipal services provision for them.

There has been only minor change in the three countries' legislation on public responsibility to offer care services, and the municipal unit remains the executive of this responsibility. All three countries stated the municipal obligation to offer home care services and residential care in both 1993 and 2014.

The major difference between the countries in both 1993 and 2014 is with regard to who is entitled to the municipalities' services provision. In Sweden, services are to be offered to 'those in need'. In Norway, the municipality shall offer 'necessary' services, while Danish municipalities must provide services to those who 'cannot provide for themselves'. In all three countries, it is evident that the wording provides citizens with weak rights, as a large degree of discretion is left to the municipalities (Erlandsson, Storm, Stranz, Szebehely, \& Trydegård, 2013, p. 25; Hjemmehjælpskommissionen, 2013, p. 37; Kjellevold, 2012; Vabo, 2012).

Both Norway and Sweden offer cash-for-care schemes. In Norway, this is a legal right, while in Sweden, it is subject to municipal discretion in terms of whether the right is introduced and in regard to both the assessment of need and the benefit size. In the two countries, the amounts are too small to constitute a real alternative to receiving extensive care services in kind. In Sweden, the benefit varies between municipalities. In the capital, Stockholm, the rates are $€$ 125-495 per month, with the highest rate provided for round-the-clock care (Stockholm.se, 2015). In Norway, the benefit for privately arranged care was $€$ 85 per month in 1994 and $€ 125$ per month in 2014 (Nav.no, 2015; Otnes, 1996).

\section{Legislation on work-family facilitation in 1993}

Table 3 provides an overview of national policies in 1993 facilitating the combination of employment and care provision to elderly relatives. Such policies can represent a functional equivalent to policies that enhance the provision of municipal social services.

In 1993, Swedish and Norwegian employees had a legal right to 30 and 20 paid days a year off work, respectively, in order to provide terminal care (Linkage 2 in Figure 2). Danish employees had a legal right to a benefit when providing terminal care, which was not, however, accompanied by the right to time off. 
Only the Norwegian legislation provided the right to reduced working hours without pay for care responsibilities, but only if this was not to the disadvantage of the employer. The act does not state what constitutes a 'disadvantage'. After the agreed period of reduced working hours, the employee could resume his or her former position. No similar employment protection was found in Sweden or Denmark.

Table 3. Legislation concerning time off work, compensation for employees and compensation for family care provision in 1993. Country, right, (Legal Source)

\begin{tabular}{|c|c|c|}
\hline Sweden & Norway & Denmark \\
\hline TERMINAL CARE & TERMINAL CARE & TERMINAL CARE \\
\hline $\begin{array}{l}\text { - Up to } 30 \text { days; pay equal to sick-leave } \\
\text { benefit (Act on Time Off to Care for a } \\
\text { Next of Kin, } 1988 \S \S 4,5,20 \text { ) }\end{array}$ & $\begin{array}{l}\text { - Up to } 20 \text { days; pay equal to sick-leave } \\
\text { benefit (Change of the Social Insurance } \\
\text { Act, 1990; Social Insurance Act, } 1966 \S \\
\text { 3-24; Working Environment and } \\
\text { Employment Protection Act, } 1977 \S 33 b \text { ) }\end{array}$ & $\begin{array}{l}\text { - Duration and right to time off not } \\
\text { stated; benefit tied to the carer's sick- } \\
\text { leave benefit (Change of the Social } \\
\text { Assistance Act, 1990; Ministry of } \\
\text { Finance, 1990) }\end{array}$ \\
\hline $\begin{array}{l}\text { CARE FOR A RELATIVE (ACUTE AND } \\
\text { LONG-TERM) }\end{array}$ & $\begin{array}{l}\text { CARE FOR A RELATIVE (ACUTE AND } \\
\text { LONG-TERM) }\end{array}$ & $\begin{array}{l}\text { CARE FOR A RELATIVE (ACUTE AND } \\
\text { LONG-TERM) }\end{array}$ \\
\hline - None & $\begin{array}{l}\text { - Right to reduced working hours } \\
\text { without pay. To be agreed with } \\
\text { employer (Change of the Working } \\
\text { Environment and Employment } \\
\text { Protection Act, 1982; Working } \\
\text { Environment and Employment } \\
\text { Protection Act, } 1977 \S 46 \text { A) }\end{array}$ & - None \\
\hline $\begin{array}{l}\text { CARER ALLOWANCE/ EMPLOYED } \\
\text { FAMILY CARER }\end{array}$ & $\begin{array}{l}\text { CARER ALLOWANCE/ EMPLOYED } \\
\text { FAMILY CARER }\end{array}$ & $\begin{array}{l}\text { CARER ALLOWANCE/ EMPLOYED } \\
\text { FAMILY CARER }\end{array}$ \\
\hline $\begin{array}{l}\text { - Employment as home care assistant, } \\
\text { depending on extent of need, paid to } \\
\text { caregiver (Municipal decisions) }\end{array}$ & $\begin{array}{l}\text { - The municipal health care service } \\
\text { shall provide a carer allowance and } \\
\text { respite care to persons with a } \\
\text { particularly heavy care burden (Change } \\
\text { of the Municipal Health Care Act, } 1986 ; \\
\text { Municipal Health Care Act, } 1982 \S 1-3 \text { ) }\end{array}$ & - None \\
\hline RESPITE TO FAMILY CARERS & RESPITE TO FAMILY CARERS & RESPITE TO FAMILY CARERS \\
\hline - None & $\begin{array}{l}\text { - The municipal health care services } \\
\text { and the social services shall provide a } \\
\text { carer allowance and respite care to } \\
\text { persons with a particularly heavy care } \\
\text { burden (Change of the Municipal Health } \\
\text { Care Act, 1986; Municipal Health Care } \\
\text { Act, 1982 §1-3; Social Services Act, } \\
\text { 1991) }\end{array}$ & $\begin{array}{l}\text { - Home carers can occasionally provide } \\
\text { relief to persons who care for a child or } \\
\text { adult with physical or mental illnesses in } \\
\text { the home (Social Assistance Act, } 1992 \\
\S 52 \text { ) }\end{array}$ \\
\hline
\end{tabular}

In Sweden, some municipalities provided the possibility of employment as a family carer (Linkage 5 in Figure 2). This was not a national scheme. The scope 
of the employment depended on the care recipient's care needs. In Norway, the municipality was obliged to offer a carer allowance to persons with a particularly heavy care burden (Linkage 3 in Figure 2). The allowance was called a salary, but carers were not employed as such; they had a temporary contract, and the pay did not include contributions towards pensions or sick leave benefits. The allowance was based on an individual overall assessment of the care recipient's needs and was paid by the hour. Denmark had no similar scheme. Swedish municipalities were not obliged to provide respite to family carers until 1997. In Norway, the municipality had an obligation to offer respite to persons with a particularly heavy care burden, while in Denmark, a family carer could receive respite provided by municipal home carers.

\section{Legislation on work-family facilitation in 2014}

Table 4 presents the regulations on support for family care as of 2014. In all three countries, employees have a right to time off work to provide terminal care, accompanied by benefits tied to the employee's sick leave benefit. Swedish and Norwegian employees have a right to 100 and 60 days a year with remuneration, respectively. The Danish Social Services Act does not impose a time limit on either the absence or the benefit. The act's regulation specifies, however, that the prognosis has to be a life expectancy of two to six months (Guide on care services, 2015).

The Scandinavian countries provide every employee with the right to take time off due to urgent family matters, but this is limited to a few days a year. In Sweden and Denmark, this is restricted to when the employee is urgently required by the family due to illnesses and accidents. In Norway, since 2010, every employee has the right to take off up to ten days a year to care for a relative. This right is directed primarily towards attending to specific care needs rather than to daily care. Norwegian employees also have the right to work reduced hours due to care responsibilities, but without pay and only if this is not to the disadvantage of the employer. In Sweden, there is no right to time off work to provide long-term care for a relative. Nor does such a right exist in Denmark, with one exception: Danish employees are entitled to a leave of absence to care for a family member when the care needs would otherwise require a full-time carer or institutionalization. The municipality employs the caregiver and, while the leave is remunerated, it requires a specific illness or a severe handicap, has a time limit of six months and is hence not suited for care purposes related to general ageing and frailty. The reason the right was introduced in 2002 was to smoothen the transition period for the family in cases of abrupt illness or handicap and to ensure the continued workforce attachment of the relatives (BSF 187, 2001). These schemes are all related to linkage 2 in Figure 2.

Sweden introduced the Freedom of Choice Act in 2008, but its implementation is at the discretion of the Swedish municipalities and, hence, it is not a national scheme (Linkage 5 in Figure 2). The act invites the care recipient to choose between a care provider and a family carer. The remuneration does not equate to a normal salary but is rather 'a symbolic sum' (Sand, 2010). Norwegian municipalities are obliged to offer a carer allowance to persons with a particularly heavy care burden (Linkage 3 in Figure 2). The scheme is national, but the municipalities assess both the need for the allowance and the rates, and the carer does not have an entitlement to the allowance. In other words, it is supply-conditioned. On average, in 2002, family carers were compensated for 10.5 hours per week and received $€ 10$ per hour (Helsetilsynet, 2009). The Danish care recipient has been able to choose the care services provider since

NJSR - Nordic Journal of Social Research

Vol. 9, 2018 
the introduction of the new Social Services Act in 1998. However, the right to formal employment as family carers depends on a municipal assessment of care needs and approval from the municipality. In all three countries, the municipality is required to provide respite care to family carers. Respite care usually consists of home care services or short-term stays in residential care facilities.

Table 4. Legislation concerning time off work, compensation for employees and compensation for family care provision in 2014. Country, right, (Legal Source)

\begin{tabular}{|c|c|c|}
\hline Sweden & Norway & Denmark \\
\hline TERMINAL CARE & TERMINAL CARE & TERMINAL CARE \\
\hline $\begin{array}{l}\text { - Up to } 100 \text { days; pay equal to sick- } \\
\text { leave benefit (Act on Time Off to Care } \\
\text { for a Next of Kin, } 1988 \S 20 \text {; Social } \\
\text { Insurance Act, } 2010 \mathrm{ch} 47 \text { ) }\end{array}$ & $\begin{array}{l}\text { - Up to } 60 \text { days; pay equal to sick-leave } \\
\text { benefit (Social Insurance Act, } 1997 \S 9- \\
\text { 1; Working Environment and } \\
\text { Employment Protection Act, } 2005 \S 12- \\
\text { 10) }\end{array}$ & $\begin{array}{l}\text { - Duration not stated; tied to the carer's } \\
\text { sick-leave benefit (Act on Time Off } \\
\text { Employment Due to Emergent Family } \\
\text { Matters, 2006 §1; Social Services Act, } \\
2014 \S \S 119-120 \text { ) }\end{array}$ \\
\hline $\begin{array}{l}\text { CARE FOR A RELATIVE (ACUTE AND } \\
\text { LONG-TERM) }\end{array}$ & $\begin{array}{l}\text { CARE FOR A RELATIVE (ACUTE AND } \\
\text { LONG-TERM) }\end{array}$ & $\begin{array}{l}\text { CARE FOR A RELATIVE (ACUTE AND } \\
\text { LONG-TERM) }\end{array}$ \\
\hline \multirow[t]{2}{*}{$\begin{array}{l}\text { - 'A certain number of days a year' (Act } \\
\text { on Time Off Employment Due to } \\
\text { Emergent Family Matters, } 1998 \S \S 1-2 \text { ) }\end{array}$} & $\begin{array}{l}\text { - Up to } 10 \text { days/year (Working } \\
\text { Environment and Employment } \\
\text { Protection Act, } 2005 \S 12-10 \text { ) }\end{array}$ & $\begin{array}{l}\text { - 'When urgently required' (Act on Time } \\
\text { Off Employment Due to Emergent } \\
\text { Family Matters, } 2006 \S 1 \text { ) }\end{array}$ \\
\hline & $\begin{array}{l}\text { - Right to reduced working hours } \\
\text { without pay. To be agreed with } \\
\text { employer (Working Environment and } \\
\text { Employment Protection Act, } 2005 \S 10- \\
\text { 2) }\end{array}$ & $\begin{array}{l}\text { - Care for a family member when the } \\
\text { care needs equal full-time employment } \\
\text { or institutionalization. Up to } 6 \text { months, } € \\
2,220 \text { /month (2014) (Act on Time Off } \\
\text { Employment Due to Emergent Family } \\
\text { Matters, } 2006 \S 1 \text {; BSF } 187,2001 \text {; } \\
\text { Social Services Act, } 2014 \S 118 \text { ) }\end{array}$ \\
\hline $\begin{array}{l}\text { CARER ALLOWANCE/ EMPLOYED } \\
\text { FAMILY CARER }\end{array}$ & $\begin{array}{l}\text { CARER ALLOWANCE/ EMPLOYED } \\
\text { FAMILY CARER }\end{array}$ & $\begin{array}{l}\text { CARER ALLOWANCE/ EMPLOYED } \\
\text { FAMILY CARER }\end{array}$ \\
\hline $\begin{array}{l}\text { - Employment as home care assistant, } \\
\text { depending on extent of need, paid to } \\
\text { caregiver (Municipal decisions) }\end{array}$ & $\begin{array}{l}\text { - The municipality shall offer a carer } \\
\text { allowance to persons with a particularly } \\
\text { heavy care burden (Municipal Health- } \\
\text { and Care Services Act, } 2011 \text { §3-6) }\end{array}$ & $\begin{array}{l}\text { - A person entitled to care services can } \\
\text { choose the provider. The municipality } \\
\text { must approve the provider. Salary paid } \\
\text { to caregiver, depending on extent of } \\
\text { need (Social Services Act, } 2014 \S 94 \text { ) }\end{array}$ \\
\hline RESPITE TO FAMILY CARERS & RESPITE TO FAMILY CARERS & RESPITE TO FAMILY CARERS \\
\hline $\begin{array}{l}\text { - The social services shall offer respite } \\
\text { care to provide relief to persons with a } \\
\text { particularly heavy care burden (Change } \\
\text { of the Social Services Act, 2009; Social } \\
\text { Services Act, } 2001 \text { ch5, §10) }\end{array}$ & $\begin{array}{l}\text { - The municipality is responsible for } \\
\text { respite care and providing relief to } \\
\text { persons with a particularly heavy care } \\
\text { burden (Municipal Health- and Care } \\
\text { Services Act, } 2011 \text { §3-2; Patients' } \\
\text { Rights Act, } 1999 \text { §2-8) }\end{array}$ & $\begin{array}{l}\text { - The municipality shall offer respite } \\
\text { care to spouses, parents or other next } \\
\text { of kin caring for a person with reduced } \\
\text { physical or mental abilities (Social } \\
\text { Services Act, } 2014 \S 84 \text { ) }\end{array}$ \\
\hline
\end{tabular}




\section{Changes in legislation on work-family facilitation between 1993 and 2014}

Between 1993 and 2014, all three countries expanded the legal right connected to combining work and family obligations, but only in cases of short-term or acute need. Norway has maintained the legal right to work reduced hours due to care obligations. Although unpaid, it provides Norwegian employees with a large degree of employment protection, which is not matched by Swedish or Danish legislation. Although Sweden has introduced the Freedom of Choice Act, employment as a family carer is still at the discretion of the municipalities. In Denmark, the possibility of employment as a family carer exists as a national scheme. Hence, Danes and Swedes who are employed as family carers maintain their rights as employees in the social insurance system while providing family care. Norwegians who receive the carer allowance do not maintain these rights. In all Scandinavian countries, the right to schemes, such as carer allowances and employment as a family carer, depends on municipal provision. In Sweden, it is entirely up to the municipality (Linkage 5 in Figure 2), while in Norway and Denmark, it is a national scheme and is, consequently, a supply-conditioned right (Linkage 3 in Figure 2).

\section{Discussion and conclusion}

This article's research question was whether legal rights provided through national legislation on services provision in Scandinavia have become, over time, more accommodating to the role of family caregiving to elderly relatives. To answer the question, it has conducted a comparison and analysis of changes in legislation between 1993 and 2014 in the three Scandinavian countries, limited to legislation on the right to eldercare services and on work-family facilitating policies in relation to the provision of care to an elderly relative. The purpose is to provide an empirical foundation for the future discussion of the degree and type of de-familialism in the Nordic welfare states.

Changes in the coverage level of municipal eldercare services between 1993 and 2014 have shown a converging trend between the Scandinavian countries. Coverage levels are converging towards Sweden, or the country with the lowest level. At the same time, national legislation in all three countries has strengthened the individual right to care services and reinforced the municipal obligation to provide such services. As of 2014, there is a legal right to care services, and in all three countries, the municipalities are obliged to offer both home care services and residential care. However, access is subject to municipal discretion, as legislation does not grant a specific right to a specific service under a specific circumstance. Hence, whereas policy statements in national legislation increasingly reinforce the right to care services, coverage levels of eldercare are declining in municipal practice. These developments suggest that the discrepancy between national policy and local practice within eldercare has increased over the years.

The organisation of eldercare in the Scandinavian countries implies that the state has limited authority over services provision (Spicker, 2008, p. 135). Similarly, national legislation, funding systems and policy goals limit local government autonomy (Hatland, 2007, p. 214). One alternative to present organisation of care services provision would be to move the responsibility for eldercare to the national level. Another alternative would be direct state funding of municipal eldercare services. However, it is hard to imagine granting 
eldercare services without the use of discretion. As a result, irrespective of organisation, the right to these services would still be weak and subject to availability, because resources are limited also at the national level.

The declining trend in coverage levels in Denmark and Norway suggests a stronger role for the family in eldercare, implying that the family is already important in Sweden. For care recipients, public and family care can be thought of as functional equivalents, provided that care needs are met (Saraceno, 2010, p. 41). For caregivers, this is less so. When providing care for a family member, carers may lose income, welfare protection and their attachment to the ordinary workforce. Therefore, an important question is whether these developments are accompanied by national policies that facilitate combining employment in the formal economy with caring for elderly family members without large prohibitive costs for the caregiver. Between 1993 and 2014, in all three Scandinavian countries, the legal rights associated with combining work and family obligations expanded in cases of short-term or acute need. Norway has kept the possibility of working reduced hours, which represents an employment protection for employees. At the same time, there is no legal right to compensation for loss of income, so the choice is between ordinary employment and unpaid caregiving. In both Sweden and Denmark, changes in legislation on employment as family carers was a result of changes in legislation on the freedom of choice of provider. The schemes in both countries are designed to provide choice to the care recipient, not to the care provider. As neither country has introduced the same employment protection as that afforded to Norwegian employees, the Danish and Swedish care provider has to choose between maintaining an attachment to ordinary employment or providing (remunerated) care.

The legislation in all three Scandinavian countries demonstrates that employees have 'a right' to time off and 'a right' to compensation for providing short-term care. These regulations can be defined as exemptions from the 'duty to work' and as work-family facilitating. They are, however, not adapted to situations where an elderly relative requires long-term family care. Corresponding schemes related to long-term family caregiving are not tied to workforce participation and are subject to municipal discretion. The wording of these supply-conditioned rights is different from the wording of the legal rights connected to short-term care obligations; instead of 'employee' and 'right', the words used are 'relative' and 'apply'. As a result, the availability of these schemes to carers is affected by other factors, such as municipal finances and the applicant's social network (Jakobsson, Kotsadam, Syse, \& Øien, 2015; Rauch, 2007, 2008). As of 2014, there are still few truly work-family facilitating schemes for eldercare provision in these countries. A caregiver has to factor in potentially large punitive costs when choosing between employment and caregiving.

The meaning of de-familialisation is usually limited to removing the responsibility for care provision from the family, and thereby increasing the independence of both caregiver and care recipient (Leitner, 2003; McLaughlin \& Glendinning, 1994, p. 65). Another important element of de-familialisation is often overlooked: economic independence from family relationships (Lister, 1994). This implies that care does not need to be removed from the family to obtain defamilialisation, but rather can be obtained by remunerating family care, albeit in combination with public care services provision. Simply providing public care services that remove the responsibility for the provision of (extensive) care from the family does not create a choice but makes the degree of de-familialisation dependent on actual public services provision. The ageing Scandinavian countries may benefit from introducing work-family facilitating policies that create an actual option for family caregivers to provide care without large 
prohibitive costs. This way, the degree of de-familialisation not only depends on public services provision but also includes the extent to which family members are economically independent. A limited extent of work-family facilitating policies for eldercare, coupled with the declining coverage levels of municipal care services, can jeopardize the high female employment rates and female economic independence from family relationships. It may also imply that the ageing Scandinavian countries are gravitating towards what Saraceno (2010) labels 'familialism by default'.

One possible explanation for the limited legal protection of family carers in Scandinavia is related to the tenet of national governments that care is mainly a public responsibility. When the responsibility is public and provision is high, there would be no need for introducing work-family facilitating policies as a safety net for when needs are not met by the public care services. Another explanation is that a strengthening of work-family facilitating policies can be interpreted as an attempt to retrench public responsibility for care services. In Sweden, there are examples of municipalities not granting care services because of the availability of family members, pointing to the wording in the Social Services Act $(2001$, ch $4, \S 1)$ that states services are for persons whose needs cannot be met in any other way. What is puzzling is that although there are large debates about the privatisation of care services provision and the value of personal choice in the Scandinavian countries, there are no strong demands for being able to choose to provide care for elderly relatives or friends without large prohibitive costs. This is contrary to debates on parents' rights to care for their children and inclusion of the voluntary sector in the care services.

After decades of policies aimed at the provision of public care services relieving the family of a large care burden and contributing to the de-familialised profile of the Scandinavian welfare state, the transition to policies that enable increased family responsibility for caregiving is challenging. The ageing of the population, the sustainability of the public welfare services and the dual-earner model limiting the caring potential of families are challenges that call for new solutions. The current dilemma of the Nordic welfare states is whether to passively continue with a high, but declining, level of public service provision of eldercare, leaving unmet care needs to unpaid family carers, or whether to introduce work-family facilitating policies enabling remunerated family care in addition to extensive public services provision.

\section{References}

Act on Time Off Employment Due to Emergent Family Matters. (1998). Act No. 209 of 7 May 1998. Lag om rätt till ledighet av trängande familjeskäl (Sweden). Retrieved from https://www.riksdagen.se/sv/dokument-lagar/dokument/svenskforfattningssamling/lag-1998209-om-ratt-till-ledighet-av-trangande sfs-1998-209

Act on Time Off Employment Due to Emergent Family Matters. (2006). Act No. 223 of 22 March 2006. Lov om lønmodtageres ret til fravær fra arbejde af særlige familiemæssige årsager (Denmark). Retrieved from https://www.retsinformation.dk/eli/lta/2006/223

Act on Time Off to Care for a Next of Kin. (1988). Act No. 1465 of 15 December 1988. Lag om ledighet för närståendevård (Sweden). Retrieved from https://www.riksdagen.se/sv/dokument-lagar/dokument/svenskforfattningssamling/lag-19881465-om-ledighet-for-narstaendevard sfs-1988$\underline{1465}$ 
Andreotti, A., Mingione, E., \& Polizzi, E. (2012). Local welfare systems: A challenge for social cohesion. Urban Studies, 49(9), 1925-1940.

https://doi.org/10.1177/0042098012444884

BSF 187. (2001). Forslag til Folketingsbeslutning om orlov til pasning af handicappede ægtefæller eller pårørende i eget hjem. [Parliament proposal on leave to care for a disabled spouse or relative in their own homes]. Socialministeriet.

Change of the Municipal Health Care Act. (1986). Act No. 55 of 11 July 1986. Lov om endringer i lov av 19. november $1982 \mathrm{nr} .66$ om helsetjenesten i kommunene og i andre lover (Norway). Sosialdepartementet.

Change of the Social Assistance Act. (1990). Act No. 256 of 25 April 1990. Forslag til lov om ændring af lov om social bistand $§ 57 \mathrm{a}$ - indførelse af plejevederlag m.v. ved pasning af døende. [Change of the Social Assistance Act §57aintroduction of benefit for caring for dying persons] (Denmark). Retrieved from https://www.retsinformation.dk/eli/ft/198912K00054

Change of the Social Insurance Act. (1990). Act No. 34 of 15 June 1990. Lov om endringer i lov av 17. juni $1966 \mathrm{nr} .12$ om folketrygd og i visse andre lover (Norway). Sosialdepartementet.

Change of the Social Insurance Act. (1991). Act No. 90 of 20 December 1991. Lov om endringer i lov av 17. juni $1966 \mathrm{nr} .12$ om folketrygd og i visse andre lover (Norway). Sosialdepartementet.

Change of the Social Services Act. (2009). Act No. 549 of 1 July 2009. Lag om ändring i socialtjänstlagen, lag 2001:453 (Sweden). Retrieved from http://rinfo.stage.lagrummet.se//publ/sfs/2009:549/pdf,sv

Change of the Social Services Act. (2010). Act No. 427 of 27 May 2010. Lag om ändring i socialtjänstlagen, lag 2001:453 (Sweden). Retrieved from http://rinfo.stage.lagrummet.se//publ/sfs/2010:427/pdf,sv

Change of the Working Environment and Employment Protection Act. (1982). Act No. 91 of 17 December 1982. Lov om endring i lov 4. februar 1977 nr. 4 om arbeidervern og arbeidsmiljø m.v. (Norway). Arbeids- og sosialdepartementet.

Daatland, S. O. (Ed.). (2014). Boliggjøring av eldreomsorgen? [Elder care in ordinary housing?] Nova rapport 16/2014. Oslo: Nova.

Daatland, S. O., Veenstra, M., \& Lima, I. A. (2010). Norwegian sandwiches. European Journal of Ageing, 7(4), 271-281. https://doi.org/10.1007/s10433-010-0163-3

Dean, H. (2014). Welfare rights and social policy. London and New York: Routledge.

Edebalk, P. G., \& Svensson, M. (2005). Kundval för äldre och funktionshindrade $i$ Norden: Konsumentperspektivet. [Customer choice for the elderly and disabled in the Nordic countries: The consumer perspective]. TemaNord report 2005:507. Retreived from http://portal.research.lu.se/portal/files/6057167/625347.pdf

Erlandsson, S., Storm, P., Stranz, A., Szebehely, M., \& Trydegård, G. B. (2013). Marketising trends in Swedish eldercare: Competition, choice and calls for stricter regulation. In G. Meagher \& M. Szebehely (Eds.), Marketisation in Nordic eldercare: A research report on legislation, oversight, extent and consequences (pp. 23-84). Stockholm Studies in Social Work 30. Stockholm University: Department of Social Work.

Esping-Andersen, G. (1990). Three worlds of welfare capitalism. Cambridge: Polity Press. 
Esping-Andersen, G. (1999). Social foundations of postindustrial economies. Oxford: Oxford University Press. https://doi.org/10.1093/0198742002.001.0001

Fimreite, A. L. (2003). Velferdsstat og lokaldemokrati - uforenlige størrelser? [Welfare state and local democracy - incompatible values?]. Norsk statsvitenskapelig tidsskrift, 19(03), 334-329.

Freedom of Choice Act. (2008). Act No. 962 of 20 November 2008. Lag om valfrihetssystem (Sweden). Retrieved from http://www.riksdagen.se/sv/dokument-lagar/dokument/svenskforfattningssamling/lag-2008962-om-valfrihetssystem sfs-2008-962

Gautun, H. (2008). Arbeidstakere og omsorg for gamle foreldre - den nye tidsklemma. [Employment and caring for older parents - the new time squeeze]. Fafo rapport 2008:40. Oslo: Fafo.

Greenhaus, J. H., \& Beutell, N. J. (1985). Sources of conflict between work and family roles. The Academy of Management Review, 10(1), 76-88. https://doi.org/10.2307/258214

Grønlie, T. (2004). Fra velferdskommune til velferdsstat - hundre års velstandsvekst fra lokalisme til statsdominans. [From welfare municipality to welfare state hundred years of prosperity growth from localism to state domination]. Historisk tidsskrift, 83(4), 633-649.

Hatland, A. (2007). Velferdsrettigheter - et styringsmiddel under press. [Welfare rights - a management tool under pressure.] Tidsskrift for velferdsforskning, 10(4), 208-220.

Health Care Act. (1982). Act No. 763 of 30 June 1982. Hälso- och sjukvårdslag (Sweden). Retrieved from https://www.riksdagen.se/sv/dokumentlagar/dokument/svensk-forfattningssamling/halso--och-sjukvardslag1982763 sfs-1982-763

Helsetilsynet. (2009). Omsorgslønnsordningen - en kunnskapsoppsummering. [Carer allowance - a knowledge summary]. Internserien 7/2009. Oslo: Statens helsetilsyn.

Hjemmehjælpskommissionen. (2013). Fremtidens hjemmehjælp - ældres ressourcer i centrum for en sammenhængende indsats. [The future of home care services the elderly's resources at the centre of a coherent effort]. Social- og integrationsministeriet.

Jakobsson, N., Kotsadam, A., Syse, A., \& Øien, H. (2015). Gender bias in public longterm care? A survey experiment among care managers. Journal of Economic Behavior \& Organization. https://doi.org/10.1016/j.jebo.2015.09.004

Jakobsson, N., Kotsadam, A., \& Szebehely, M. (2013). Informal eldercare and care for disabled children in the Nordic countries: Prevalence and relation to employment. Nordic Journal of Social Research, 4, 1-30. https://doi.org/10.7577/njsr.2064

Jensen, P. H., \& Lolle, H. (2013). The fragmented welfare state: Explaining local variations in services for older people. Journal of Social Policy, 42(02), 349-370. https://doi.org/10.1017/S0047279412001006

Kjellevold, A. (2012). Ny lov om kommunale helse- og omsorgstjenester: verdivalg og rettslig regulering. [New municipal health and care services act: value choices and legal regulation]. Tidsskrift for erstatningsrett, forsikringsrett og velferdsrett, 9(1-2), 15-44. 
KMD. (2015). Inntektssystemet for kommunene. [The municipal income system]. Retrieved from https://www.regjeringen.no/no/tema/kommuner-ogregioner/kommuneokonomi/inntektssystemet-for-kommuner-ogfylkeskommuner1/id2353961/

Knijn, T., \& Kremer, M. (1997). Gender and the caring dimension of welfare states: Toward inclusive citizenship. Social Politics: International Studies in Gender, State \& Society, 4(3), 328-361. https://doi.org/10.1093/oxfordjournals.sp.a034270

Korpi, W. (2000). Faces of inequality: Gender, class, and patterns of inequalities in different types of welfare states. Social Politics: International Studies in Gender, State \& Society, 7(2), 127-191. https://doi.org/10.1093/sp/7.2.127

Kröger, T. (2001). Comparative research on social care: The state of the art SOCCARE Project Report 1: European Commission 5th Framework Programme.

Leira, A., \& Saraceno, C. (2002). Care: Actors, relationships and contexts. In B. Hobson, J. Lewis, \& B. Siim (Eds.), Contested concepts in gender and social politics (pp. 55-83). Cheltenham: Edward Elgar. https://doi.org/10.4337/9781781950340.00007

Leitner, S. (2003). Varieties of familialism - The caring function of the family in comparative perspective. European Societies, 5(4), 353-375. https://doi.org/10.1080/1461669032000127642

Lewinter, M. (2004). Developments in home help for elderly people in Denmark: The changing concept of home and institution. International Journal of Social Welfare, 13(1), 89-96. https://doi.org/10.1111//.1369-6866.2004.00300.x

Lewis, J., \& Giullari, S. (2005). The adult worker model family, gender equality and care: The search for new policy principles and the possibilities and problems of a capabilities approach. Economy and Society, 34(1), 76-104. https://doi.org/10.1080/0308514042000329342

Lister, R. (1994). 'She has other duties' - Women, citizenship and social security. In S. Baldwin \& J. Falkingham (Eds.), Social security and social change: New challenges to the Beveridge model (pp. 31-44). London: Harvester Wheatsheaf.

McLaughlin, E., \& Glendinning, C. (1994). Paying for care in Europe: Is there a feminist approach? In L. Hantrais \& S. P. Mangen (Eds.), Family policy and the welfare of women (pp. 52-69). Loughborough University of Technology: European Research Centre.

Ministry of Finance. (1990). Circulære om tjenestefrihed $m v$ for ansatte i staten, folkeskolen og folkekirken til pasning af døende i hjemmet. [Circular on time off employment, etc., for employees in government, elementary schools and the state church for providing care to persons dying at home]. APD.nr. 102/90. Finansministeriet Administrations- og Personaldepartementet.

Municipal Health and Care Services Act. (2011). Act No. 30 of 24 June 2011. Lov om kommunale helse- og omsorgstjenester (Norway). Retrieved from https://lovdata.no/dokument/NL/lov/2011-06-24-30

Municipal Health Care Act. (1982). Act No. 66 of 19 November 1982. Lov om helsetjenesten i kommunene (Norway). Helse- og omsorgsdepartementet.

Nav.no. (2015). Satser folketrygdloven § 6-4 [Allowance rates National Insurance Act § 6-4]. Retrieved from https://www.nav.no/rettskildene/Vedlegg/vedlegg-2-tilkapittel-6-6-4-satser

NJSR - Nordic Journal of Social Research 
Nielsen, J. A., \& Andersen, J. G. (2006). Hjemmehjælp mellem myter og virkelighed. [Home care services between myths and reality]. Odense: Syddansk universitetsforlag.

NOSOSCO. (1995-2015). Social Protection in the Nordic Countries Scope, Expenditure and Financing Nordic Social Statistical Committee. All volumes.

Otnes, B. (1996). Statistikk om egenbetaling: Forprosjekt. [Statistics on user payments: Pre-project]. SSB Notat 96/13. Oslo: SSB.

Otnes, B. (2015). Utviklingen i pleie- og omsorgstjenestene 1994-2013. [Developments in care services 1994-2013]. Tidsskrift for omsorgsforskning, 1(01), 48-61.

Patients' Rights Act. (1999). Act No. 63 of 2 July 1999. Lov om pasient- og brukerrettigheter (Norway). Retrieved from https://lovdata.no/dokument/NL/lov/1999-07-02-63

Powell, M., \& Boyne, G. (2001). The spatial strategy of equality and the spatial division of welfare. Social Policy \& Administration, 35(2), 181-194. https://doi.org/10.1111/1467-9515.00226

Prop 14 (1990/91). Regeringens proposition 1990/91:14 om ansvaret för service och vård till äldre och handikappade m. m. [Government Bill 1990/91: 14 on the responsibility for services and care for the elderly and the disabled, etc.]. Regeringen.

Prop. 91 L (2010-2011). Lov om kommunale helse- og omsorgstjenester. [Act on municipal health and care services]. Helse- og omsorgsdepartementet.

Rauch, D. (2007). Is there really a Scandinavian social service model? A comparison of childcare and elderlycare in six European countries. Acta Sociologica, 50(3), 249-269. https://doi.org/10.1177/0001699307080931

Rauch, D. (2008). Central versus local service regulation: Accounting for diverging oldage care developments in Sweden and Denmark, 1980-2000. Social Policy \& Administration, 42(3), 267-287. https://doi.org/10.1111/j.1467$\underline{9515.2007 .00596 . x}$

Revillard, A. (2006). Work/family policy in France: From state familialism to state feminism? International Journal of Law, Policy and the Family, 20(2), 133-150. https://doi.org/10.1093/lawfam/ebl009

Sand, A. B. (2010). Anhöriga som kombinerar förvärvsarbete och anhörigomsorg. [Relatives who combine employment and family care]. Kunskapsöversikt 2010:1. Kalmar: Nationellt kompetenscentrum anhöriga.

Saraceno, C. (2010). Social inequalities in facing old-age dependency: A bigenerational perspective. Journal of European Social Policy, 20(1), 32-44. https://doi.org/10.1177/0958928709352540

Sartori, G. (2009). Comparing and miscomparing. In D. Collier \& J. Gerring (Eds.), Concepts and methods in social science: The tradition of Giovanni Sartori. New York: Routledge.

Sipilä, J., Andersson, M., Hammarqvist, S. E., Nordlander, L., Rauhala, P. L., Thomsen, K., \& Warming Nielsen, H. (1997). A multitude of universal, public services-How and why did four Scandinavian countries get their social care service model. In J. Sipilä (Ed.), Social care services: The key to the Scandinavian welfare model. Aldershot: Ashgate Publishing Limited. 
Social Assistance Act. (1992). Act No. 829 of 1 October 1992. Bekendtgørelse af lov om social bistand (Denmark). Retrieved from https://www.retsinformation.dk/Forms/R0710.aspx?id=53762

Social Care Act. (1964). Act No. 2 of 5 June 1964. Lov om sosial omsorg av 5. juni 1964 med endringslover sist av 1. juni 1973 (Norway). Sosialdepartementet.

Social Insurance Act. (1966). Act No. 12 of 17 June 1966. Lov om folketrygd (Norway). Sosialdepartementet.

Social Insurance Act. (1997). Act No 19 of 28 February 1997. Lov om folketrygd (Norway). Retrieved from https://lovdata.no/dokument/NL/lov/1997-02-28-19

Social Insurance Act. (2010). Act No. 110 of 4 March 2010. Socialförsäkringsbalk (Sweden). Retrieved from https://www.riksdagen.se/sv/dokumentlagar/dokument/svensk-forfattningssamling/socialforsakringsbalk-2010110 sfs$\underline{2010-110}$

Social Services Act. (1980). Act No. 620 of 19 June 1980. Socialtjänstlag (Sweden). Retrieved from https://www.riksdagen.se/sv/dokument-lagar/dokument/svenskforfattningssamling/socialtjanstlag-1980620 sfs-1980-620

Social Services Act. (1991). Act No. 81 of 13 December 1991. Sosialtjenesteloven (Norway). Arbeids- og sosialdepartementet.

Social Services Act. (2001). Act No. 7 June 2003. Socialtjänstlagen (Sweden). Retrieved from https://www.riksdagen.se/sv/dokument-lagar/dokument/svenskforfattningssamling/socialtjanstlag-2001453 sfs-2001-453

Social Services Act. (2014). Act No.1023 of 23 November 2014. Serviceloven (Denmark). Retrieved from https://www.retsinformation.dk/pdfprint.aspx?id=164215

Spicker, P. (2008). Social policy: Themes and approaches. Bristol: Policy Press.

Stockholm.se. (2015). Stockholm Hemvårdsbidrag. [Stockholm home care allowance] Retrieved from http://www.stockholm.se/PageFiles/116363/Hemv\%c3\%a5rdsbidrag\%20belopp \%202015.pdf

Szebehely, M., \& Trydegård, G. B. (2007). Omsorgstjänster för äldre och funktionshindrade: skilda villkor, skilda trender? [Care services for the elderly and the disabled: different conditions, different trends?]. Socialvetenskaplig tidskrift, 14(2-3), 197-219.

Trydegård, G. B., \& Thorslund, M. (2010). One uniform welfare state or a multitude of welfare municipalities? The evolution of local variation in Swedish elder care. Social Policy \& Administration, 44(4), 495-511. https://doi.org/10.1111/j.1467$\underline{9515.2010 .00725 . x}$

Vabo, S. I. (2012). Tiltakende statlig styring av kommunesektoren - også på eldreområdet? [Increasing state governance of the municipal sector - also in elder care?] In M. Reitan, J. Saglie, \& E. Smith (Eds.), Det norske flernivådemokratiet. [The Norwegian multi-level democracy]. Oslo: Abstrakt forlag.

Vabø, M., \& Szebehely, M. (2012). A caring state for all older people? In A. Anttonen, L. Häikiö, \& K. Stefánsson (Eds.), Welfare state, universalism and diversity (pp. 121-143). Cheltenham: Edward Elgar. https://doi.org/10.4337/9781849805940.00012 
van Gestel, N., \& Herbillon, J. M. (2010). Rescaling of social welfare policies: Lessons and future perspectives. In Y. Kazepov (Ed.), Rescaling social policies: Towards multilevel governance in Europe (pp. 415-428). Surrey: Ashgate Publishing Ltd.

Guide on care services (2015). Guide No. 9341 of 8 May 2015. Vejledning om hjælp og støtte efter serviceloven [Guidance on assistance and support according to the Social Services Act] (Denmark). Ministeriet for Børn Ligestilling Integration og Sociale Forhold.

Voydanoff, P. (2004). The effects of work demands and resources on work-to-family conflict and facilitation. Journal of Marriage and Family, 66(2), 398-412. https://doi.org/10.1111/j.1741-3737.2004.00028.x

Working Environment and Employment Protection Act. (1977). Act No. 4 of 4 February 1977. Lov om arbeidervern og arbeidsmiljø mv. (Norway). Arbeids- og sosialdepartementet.

Working Environment and Employment Protection Act. (2005). Act No. 62 of 17 June 2005. Lov om arbeidsmiljø arbeidstid og stillingsvern (Norway). Retrieved from https://lovdata.no/dokument/NL/lov/2005-06-17-62 